\title{
Commentary on "Data on the Characteristics and the Survival of Korean Patients With Colorectal Cancer From the Korea Central Cancer Registry"
}

\author{
Mohammad Mohammadianpanah \\ Colorectal Research Center, Shiraz University of Medical Sciences, Shiraz, Iran
}

To the editor

In the July 2013 issue of Annals of Coloproctology, I read with great interest the article entitled "Data on the Characteristics and the Survival of Korean Patients with Colorectal Cancer from the Korea Central Cancer Registry" by Park et al. [1]. That study is one of the largest reports on colorectal cancer published in the literature. It provides valuable information regarding the characteristics and oncologic outcomes of Korean patients with colorectal cancer. However, in the discussion section, there was a paucity of comparisons of the characteristics and the survival of Korean patients suffering from colorectal cancer with those of European and American colorectal colorectal-cancer patients. In Korean patients, the rectum accounts for a higher proportion of colorectal-cancer primary sites compared to European and American patients [1,2]. A similar distribution is also seen in the Iranian population [3]. Table 1 illustrates the distributions of primary tumor sites of colorectal cancer in Korea, Europe, and the United States (US). Moreover, the Korean patients showed a lower proportion for localized disease and a higher proportion for regional stage compared to Euro- pean and American patients $[1,4]$ (Table 1). We also found a similar finding among Iranian patients with colorectal cancer $[3,5]$. In the study by Park et al. [1], the 5-year survival of Korean patients with colorectal cancer was $72.1 \%$, which is significantly higher than the 5-year survival rates in European countries (43\%) and the US (62\%) $[1,2,6,7]$. Therefore, a discrepancy is seen to exist between this higher 5-year survival rate and the higher proportion of stage III cancers in Korea compared to the West.

\section{REFERENCES}

1. Park HC, Shin A, Kim BW, Jung KW, Won YJ, Oh JH, et al. Data on the characteristics and the survival of korean patients with colorectal cancer from the Korea central cancer registry. Ann Coloproctol 2013;29:144-9.

2. Gatta G, Ciccolallo L, Capocaccia R, Coleman MP, Hakulinen T, Moller $\mathrm{H}$, et al. Differences in colorectal cancer survival between European and US populations: the importance of sub-site and morphology. Eur J Cancer 2003;39:2214-22.

Table 1. Clinicopathological features and overall survivals of Korean, European, and American patients with colorectal cancer [1,4]

\begin{tabular}{|c|c|c|c|c|c|c|c|c|c|}
\hline \multirow{2}{*}{ Region } & \multirow{2}{*}{ No. of patients } & \multicolumn{3}{|c|}{ Primary site (\%) } & \multirow{2}{*}{ No. of patients } & \multicolumn{4}{|c|}{ Stage $(\%)$} \\
\hline & & Rt. colon & Lt. colon & Rectum & & Localized & Regional & Metastatic & Unstaged \\
\hline Europe & 134,575 & 29 & 27 & 44 & 2,492 & 48 & 21 & 21 & 10 \\
\hline USA & 70,180 & 54 & 23 & 23 & 11,191 & 54 & 23 & 18 & 5 \\
\hline Korea & 208,924 & 22 & 26 & 52 & 113,881 & 34 & 40 & 14 & 12 \\
\hline
\end{tabular}

Rt., right; Lt., left.

Correspondence to: Mohammad Mohammadianpanah, M.D.

Colorectal Research Center, Shiraz University of Medical Sciences, Shiraz

71936, Iran

Tel: +98-711-6125170, Fax: +98-711-6474320

E-mail:mohpanah@gmail.com

(C) 2014 The Korean Society of Coloproctology

This is an open-access article distributed under the terms of the Creative Commons Attribution Non-

Commercial License (http://creativecommons.org/licenses/by-nc/3.0) which permits unrestricted non-

commercial use, distribution, and reproduction in any medium, provided the original work is properly cited. 
3. Ghahramani L, Razzaghi S, Mohammadianpanah M, Pourahmad S. Adequacy of lymph node staging in colorectal cancer: analysis of 250 patients and analytical literature review. Ann Colorectal Res 2013;1:3-11.

4. Ciccolallo L, Capocaccia R, Coleman MP, Berrino F, Coebergh JW, Damhuis RA, et al. Survival differences between European and US patients with colorectal cancer: role of stage at diagnosis and surgery. Gut 2005;54:268-73.

5. Ghahramani L, Moaddabshoar L, Razzaghi S, Hamedi SH, Pourahmad S, Mohammadianpanah M. Prognostic value of total lymph node identified and ratio of lymph nodes in resected colorectal cancer. Ann Colorectal Res 2013;1:81-91.

6. Coleman MP, Quaresma M, Berrino F, Lutz JM, De Angelis R, Capocaccia R, et al. Cancer survival in five continents: a worldwide population-based study (CONCORD). Lancet Oncol 2008; 9:730-56.

7. Koo HY, Park KJ, Oh JH, Kang SB, Oh ST, Lee WY. Investigation of clinical manifestations in korean colorectal cancer patients. Ann Coloproctol 2013;29:139-43. 